\title{
Warfarin Sodium
}

National Cancer Institute

\section{Source}

National Cancer Institute. Warfarin Sodium. NCI Thesaurus. Code C1658.

The sodium salt form of warfarin, a coumarin and a vitamin $\mathrm{K}$ antagonist, with anticoagulant activity. Warfarin sodium inhibits both vitamin $\mathrm{K}$ and vitamin $\mathrm{K}$ epoxide reductases, thereby interfering with the cyclic interconversion of vitamin $\mathrm{K}$ epoxide to its reduced form, vitamin $\mathrm{KH} 2$. Vitamin $\mathrm{KH} 2$ is a cofactor for the carboxylation of glutamate residues on the $\mathrm{N}$-terminal regions of vitamin $\mathrm{K}$-dependent proteins. As a result, maturation of vitamin K-dependent coagulation factors II, VII, IX, and X and anticoagulant proteins $\mathrm{C}$ and $\mathrm{S}$ is inhibited. Without these coagulation factors, thrombogenesis and blood clot formation are prevented. 